\title{
Oscillatory Behaviour of Isomers of Hydroxybenzoic Acid with and without Catalyst
}

\author{
Masood A. Nath,* R. P. Rastogi and G. M. Peerzada \\ Department of Chemistry, University of Kashmir, Srinagar, 190006 Jammur \& Kashmir, India
}

\begin{abstract}
O presente trabalho estabelece e compara o comportamento oscilatório dos ácidos mono-, di- e trihidroxibenzóico, como substratos orgânicos em bromato-ácido $\left(1,0 \mathrm{~mol} \mathrm{~L}^{-1} \mathrm{H}_{2} \mathrm{SO}_{4}\right)$ sem catalisador e na presença de íon $\mathrm{Mn}^{2+}$ como principal catalisador. As oscilações também são afetadas pelo uso de outro catalisador como íon $\mathrm{Fe}^{2+}$. Além disso, as oscilações diminuem em sistemas de catálise mista. Os parâmetros experimentais foram obtidos potenciometricamente e os resultados interpretados com base no mecanismo FKN.
\end{abstract}

The present work establishes and compares the oscillatory behaviour of mono-, di- and trihydroxybenzoic acids as organic substrates in acidic bromate $\left(1.0 \mathrm{~mol} \mathrm{~L}^{-1} \mathrm{H}_{2} \mathrm{SO}_{4}\right)$ without catalyst and in the presence of $\mathrm{Mn}^{2+}$ ion as the main catalyst. The oscillations are also affected by other catalyst such as $\mathrm{Fe}^{2+}$ ion. Further, the oscillations start diminishing in mixed catalyst systems. The experimental parameters were obtained potentiometrically and the results have been interpreted on the basis of FKN mechanism.

Keywords: BZ, hydroxybenzoic acid, manganese(II) ion, sulphuric acid

\section{Introduction}

The classical $\mathrm{B}-\mathrm{Z}$ reaction ${ }^{1}$ involves a metal ion redox catalyst couple such as $\mathrm{Ce}^{4+} / \mathrm{Ce}^{3+}, \mathrm{Mn}^{3+} / \mathrm{Mn}^{2+}$ or $\mathrm{Fe}^{3+} / \mathrm{Fe}^{2+}$ in addition to bromate ion, $\mathrm{H}^{+}$and the organic substrate such as malonic acid or citric acid. Orban and Koros, ${ }^{2}$ in 1978 , discovered oscillations in redox potential, bromide ion concentration and color in a system containing only sulphuric acid, bromate and organic species such as gallic acid $(3,4,5$ trihydroxybenzoic acid). This was the first class known as uncatalyzed B-Z oscillations ${ }^{3}$ which now includes 23 other organic substrates..$^{4,5}$ The substrates used by authors are aryldiazonium salts, phenol, aminophenol and their derivatives. These compounds can all be regarded as derivatives of phenol or aniline. All these compounds have hydrogen attached to oxygen or nitrogen whose abstraction would generate a resonance stabilized free radical. All these have at least one free ortho position subjected to bromination by $\mathrm{Br}_{2}$ or $\mathrm{HOBr}$. All such compounds have at least one free ortho or para position so that oxidation could generate a quinone or quinone imine structure. Thus various quinones, brominated derivatives and oxidatively coupled products may be observed.

*e-mail: nath_masood@yahoo.co.in
However, these uncatalysed oscillatory reactions are all controlled by bromide ion and the critical bromide ion concentration is similar to that observed during catalysis by metal ions. ${ }^{6}$

The oscillatory behaviour of uncatalyzed bromate driven oscillators have been explained in terms of OKN mechanism (a modification of FKN mechanism). Numerical simulations based on this mechanism by Herbine and Field ${ }^{7}$ reproduced the main features of uncatalyzed oscillations. Extended models were suggested by Liu and Scott ${ }^{8,9}$ and by Gyorgyi et al. ${ }^{10} \mathrm{~A}$ quinone derivative of the original organic reactant like gallic acid plays the role of metal ion catalyst. The mechanism involves oxidation of organic substrate by $\mathrm{BrO}_{2} \cdot$ in the following way:

$\mathrm{BrO}_{3}^{-}+\mathrm{Br}^{-}+2 \mathrm{H}^{+} \rightleftharpoons \mathrm{HBrO}_{2}+\mathrm{HOBr}$

$\mathrm{HBrO}_{2}+\mathrm{Br}^{-}+\mathrm{H}^{+} \rightarrow 2 \mathrm{HOBr}$

$\mathrm{BrO}_{3}^{-}+\mathrm{HBrO}_{2}+\mathrm{H}^{+} \rightleftharpoons 2 \mathrm{BrO}_{2}^{-}+\mathrm{H}_{2} \mathrm{O}$

$\mathrm{BrO}_{2}{ }^{\circ}+\mathrm{HAr}(\mathrm{OH})_{2} \rightarrow \mathrm{HBrO}_{2}+\mathrm{HAr}(\mathrm{OH}) \mathrm{O}^{\circ}$

$2 \mathrm{HBrO}_{2} \rightarrow \mathrm{BrO}_{3}^{-}+\mathrm{HOBr}+\mathrm{H}^{+}$

$\mathrm{HOBr}+\mathrm{HAr}(\mathrm{OH}) \mathrm{O}^{\bullet} \rightleftharpoons \mathrm{Br}^{\bullet}+\mathrm{HArO}_{2}+\mathrm{H}^{+}+\mathrm{H}_{2} \mathrm{O}(6)$ 


$$
\begin{aligned}
& \mathrm{Br}^{*}+\mathrm{HAr}(\mathrm{OH}) \mathrm{O} \rightarrow \mathrm{Br}^{-}+\mathrm{HArO}_{2}+\mathrm{H}^{+} \\
& \mathrm{HOBr}+\mathrm{Br}^{-}+\mathrm{H}^{+} \rightarrow \mathrm{Br}_{2}+\mathrm{H}_{2} \mathrm{O} \\
& \mathrm{Br}_{2}+\mathrm{HAr}(\mathrm{OH})_{2} \rightarrow \mathrm{BrAr}(\mathrm{OH})_{2}+\mathrm{Br}^{-}+\mathrm{H}^{+} \\
& \mathrm{HOBr}+\mathrm{HAr}(\mathrm{OH})_{2} \rightarrow \operatorname{BrAr}(\mathrm{OH})_{2}+\mathrm{H}_{2} \mathrm{O}
\end{aligned}
$$

To summarise, the mechanistic skeleton has four key features: (i) $\mathrm{HBrO}_{2}$ is generated autocatalytically in steps (3) and (4); (ii) bromide ion is produced by the bromination of original organic reactant species; (iii) the same process also provides a quinone derivative; $(i v) \mathrm{HAr}(\mathrm{OH})_{2}$ participates in the autocatalytic reaction.

The remaining features of inhibition by bromide and the limitation of autocatalysis by self reaction of $\mathrm{HBrO}_{2}$ are retained from the classical FKN mechanism.

Further, in adition to uncatalysed oscillators, there is a major class of oscillators known as 'Catalysed BZ oscillators'. The catalysts used in the BelousovZhabotinisky reaction should be a one electron redox couple between 0.9-1.50 V e.g, $\mathrm{Ce}^{4+} / \mathrm{Ce}^{3+}, \mathrm{Mn}^{3+} / \mathrm{Mn}^{2+}$ or $\mathrm{Fe}^{3+} / \mathrm{Fe}^{2+}$ etc. In catalysed systems FKN mechanism has been found to be satisfactory on the basis of experimental studies on the $\mathrm{B}-\mathrm{Z}$ reaction and computer modeling. The hard core of the control mechanism for generation is:

(i) Positive feedback (autocatalysis),

$\mathrm{BrO}_{3}^{-}+\mathrm{HBrO}_{2}+3 \mathrm{H}^{+}+2 \mathrm{Ce}^{3+} \rightarrow 2 \mathrm{HBrO}_{2}+2 \mathrm{Ce}^{4+}+\mathrm{H}_{2} \mathrm{O}$

(ii) Negative feedback (inhibitory reaction),

$\mathrm{HBrO}_{2}+\mathrm{Br}^{-}+\mathrm{H}^{+} \rightarrow 2 \mathrm{HOBr}$

There are other steps in the mechanism involving $\mathrm{HBrO}_{2}, \mathrm{BrO}_{2} \cdot \mathrm{HOBr}, \mathrm{Br}^{-}$, etc.

In view of the fact that the rate constant of the reaction in the negative feedback is of much smaller magnitude, it is expected that inhibitory reaction is most likely to primarily influence the oscillatory characteristics such as induction time, time period and life time.

In the present article, the effect of catalyst and other catalyst has been studied in depth. Organic substrates, having different position and number of $-\mathrm{OH}$ groups, have been chosen for detailed study, because the number and position of $-\mathrm{OH}$ groups influence the feasibility of bromination. The main objectives of the present communication are: $(i)$ to investigate the dependence of sensitivity of controlled mechanism of the B-Z reaction on the nature of organic substrate and the catalyst; (ii) to investigate the dependence of sensitivity of oscillatory characteristics of B-Z reaction on the initial conditions such as induction time, time period, life time, frequency etc.

\section{Experimental}

The chemicals used are para-hydroxybenzoic acid ( $p$-HBA), meta-hydroxybenzoic acid ( $m$-HBA), orthohydroxybenzoic acid (o-HBA), 3,4-dihydroxybenzoic acid (3,4-DHBA), 3,4,5-trihydroxybenzoic acid (gallic acid), polymeric 3,4,5-trihydroxybenzoic acid (tannic acid), manganous sulphate monohydrate and potassium bromate. The aforesaid chemicals are all analytical grade procured from Merck, Himedia, Qualigens, Fluka, SRL and BDH. The desired solutions were prepared in $1.0 \mathrm{~mol} \mathrm{~L}^{-1}$ sulphuric acid of $98 \%$ purity.

The Ion-meter (Eutech instruments Model PC-5500) having $\mathrm{pH}$ as well as $\mathrm{mV}$ option was setup in order to record change in $\mathrm{mV}$ versus time for the reaction systems. The reaction system comprising of any one of the aforesaid organic substrates, potassium bromate and $\mathrm{Mn}^{2+}$ ion solution was taken in one of the half cells into which a platinum electrode was dipped as the indicator electrode, whereas calomel electrode was taken as the reference electrode (SCE) in another half cell, containing $2.5 \times 10^{-4} \mathrm{~mol} \mathrm{~L}^{-1}$ solution of potassium chloride. The two half cells are connected through a salt bridge and kept immersed in a high precision water bath (JindalS.M. Scientific instruments) set up at desired temperature $\left(35^{\circ} \mathrm{C} \pm 0.2\right)$. The potential change in $\mathrm{mV}$ was recorded after every ten or five seconds whichever was easy to monitor.

\section{Results and Discussion}

The oscillatory characteristics are given in Table 1. From the Table it is obvious that lesser numbers of oscillations are observed in uncatalysed oscillators than in catalyzed systems. It has been suggested that there is an induction period during which all the aromatic compound (such as isomers of hydroxybenzoic acid) are converted into various brominated species and quinones which is followed by a few oscillations. Oscillations stop when all the organic material is converted into quinones and bromoderivatives. There is usually substantial bromate left at this point. Oscillations can restart if cerium or manganese ion is added, soon after the uncatalysed oscillations cease.

The temporal oscillations in the uncatalysed systems studied may be explained in terms of $\mathrm{OKN}^{11}$ mechanism and the modified OKN mechanism for dihydroxy and monohydroxybenzenes respectively. Here the role of metal ion catalyst is taken over by the aromatics to reduce 
$\mathrm{BrO}_{2}$. The formation of aromatic radical by hydrogen atom abstraction and its subsequent conversion into quinones may be responsible for the temporal oscillations, but the stoichiometry of these reacting systems is complicated. All monohydroxybenzoic acids except $o$-HBA give more oscillations as compared to phenol ${ }^{12}$ which may be due to the presence of an electron withdrawing - $\mathrm{COOH}$ group, forming a more resonance stabilized radical after hydrogen atom abstraction from the phenolic group by $\mathrm{BrO}_{2}{ }^{\circ}$ radical. In $o$-HBA, because of hydrogen bonding, hydrogen atom abstraction is difficult which results in less oscillatory behaviour.

In the 3,4-dihydroxybenzoic acid, the less oscillatory behaviour compared to monohydroxybezoic acids such as $p$-HBA can be explained by the fact that oxidation of dihydroxybenzoic acid to a stable quinone is faster than that of monohydroxybenzoic acids, the former involving a series of steps (4-7) in OKN mechanism and the latter involving steps (4-9) in the modified OKN mechanism. Similarly trihydroxybenzoic acid such as gallic acid forms the most stable quinone, hence responsible for its least oscillatory behaviour.

However, in presence of $\mathrm{Mn}^{2+}$ ion as the catalyst, the number of oscillations increases for most of these substrates except gallic acid as shown in Figure 1. This is because metal ion catalysts used in BZ reaction involve a redox couple between $0.9-1.5 \mathrm{~V}$. The oscillatory characteristics such as induction period $\left(\mathrm{I}_{\mathrm{p}}\right)$, time period (tp) and number

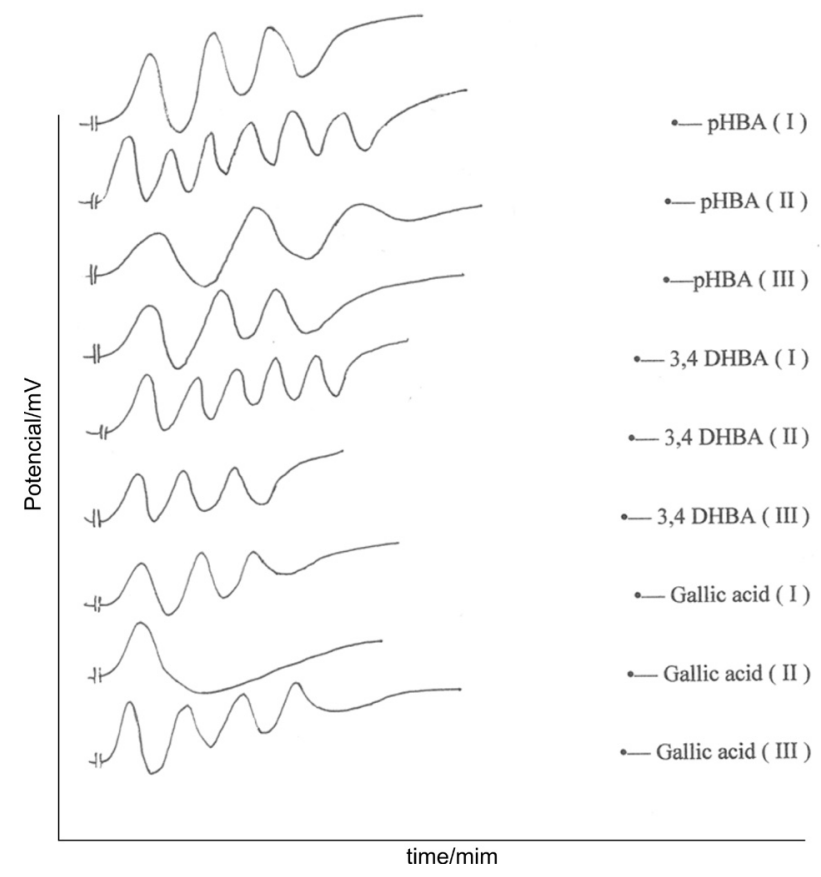

Figure 1. Oscillations of redox potential for the systems containing isomers of hydroxybenzoic acid; ( I ) without catalyst, ( II ) in presence of $\mathrm{Mn}^{2+}$, and ( III ) in presence of $\mathrm{Fe}^{2+}$.
Table 1. Oscillatory parameters of the systems containing $[o-\mathrm{HBA}]=$ $[m-\mathrm{HBA}]=[p-\mathrm{HBA}]=[3,4-\mathrm{DHBA}]=[3,4,5-\mathrm{THBA}]=0.0070 \mathrm{~mol} \mathrm{~L}^{-1}$; $\left[\mathrm{BrO}_{3}^{-}\right]=0.0750 \mathrm{~mol} \mathrm{~L}{ }^{-1},\left[\mathrm{Mn}^{2+}\right]=\left[\mathrm{Fe}^{2+}\right]=0.0080 \mathrm{~mol} \mathrm{~L}^{-1}$, $\left[\mathrm{H}_{2} \mathrm{SO}_{4}\right]=1.0 \mathrm{~mol} \mathrm{~L}^{-1} ; \mathrm{T}=35^{\circ} \mathrm{C} \pm 0.2$

\begin{tabular}{|c|c|c|c|c|}
\hline \multicolumn{2}{|l|}{ Organic substrate } & \multirow{2}{*}{$\frac{\mathrm{I}_{\mathrm{p}} / \mathrm{min}}{2.0}$} & \multirow{2}{*}{$\frac{\mathrm{t}_{\mathrm{p}} / \min }{6.8}$} & \multirow{2}{*}{$\begin{array}{c}\begin{array}{c}\text { No. of } \\
\text { Oscillations }\end{array} \\
03\end{array}$} \\
\hline$p$-HBA & Uncatalysed & & & \\
\hline Main catalyst, & $\mathrm{Mn}^{2+}$ & 1.3 & 2.7 & 06 \\
\hline Other catalyst & $\mathrm{Fe}^{2+}$ & 3.3 & 6.0 & 03 \\
\hline$m$-HBA & Uncatalysed & 2.5 & 7.5 & 02 \\
\hline Main catalyst & $\mathrm{Mn}^{2+}$ & 2.3 & 9.6 & 04 \\
\hline Other catalyst & $\mathrm{Fe}^{2+}$ & 0.6 & 2.0 & 09 \\
\hline$o$-HBA & Uncatalysed & 2.1 & 7.0 & 02 \\
\hline Main catalyst & $\mathrm{Mn}^{2+}$ & 1.6 & 5.7 & 06 \\
\hline Other catalyst & $\mathrm{Fe}^{2+}$ & 2.0 & 3.0 & 08 \\
\hline 3,4-DHBA & Uncatalysed & 3.0 & 5.0 & 03 \\
\hline Main catalyst & $\mathrm{Mn}^{2+}$ & 1.5 & 4.1 & 05 \\
\hline Other catalyst & $\mathrm{Fe}^{2+}$ & 2.0 & 5.0 & 03 \\
\hline $3,4,5$-THBA & Uncatalysed & 2.0 & 4.0 & 03 \\
\hline Main catalyst & $\mathrm{Mn}^{2+}$ & 5.0 & $*$ & 01 \\
\hline Other catalyst & $\mathrm{Fe}^{2+}$ & 1.5 & 2.33 & 04 \\
\hline Tannic acid & Uncatalysed & 2.5 & 6.0 & 02 \\
\hline Main catalyst & $\mathrm{Mn}^{2+}$ & 2.0 & 1.5 & 05 \\
\hline Other catalyst & $\mathrm{Fe}^{2+}$ & 1.8 & 1.33 & 05 \\
\hline
\end{tabular}

*Very large value that is difficult to calculate.

of oscillations are predominantly affected in presence of other catalyst such as $\mathrm{Fe}^{2+}$ ion as shown in Table 1. The number of oscillations increases for most of the isomers (except $p$-HBA) in the presence of ferroin $\left(\mathrm{Fe}^{2+}\right.$ ion) as catalyst. The difference in behaviour may be due to their redox potential and their tendency to react with the $\mathrm{BrO}_{2}$ (in the autocatalytic step) and organic species in the following steps of FKN mechanism:

$$
\begin{aligned}
& 2 \mathrm{M}^{2+}+\mathrm{BrO}_{3}{ }^{-}+3 \mathrm{H}^{+}+\mathrm{HBrO}_{2} \rightarrow 2 \mathrm{HBrO}_{2}+\mathrm{H}_{2} \mathrm{O}+2 \mathrm{M}^{3+} \\
& \mathrm{M}^{3+}+\text { Bromoderivative } \rightarrow \mathrm{M}^{2+}+\mathrm{Br}^{-}
\end{aligned}
$$

The reactivity of mono-, di- and tri-hydroxybenzoic acids with respect to $\mathrm{Fe}^{2+}$ ion follows the order:

\section{3, 4, 5-THBA $>3,4$-DHBA $>p$-HBA}

And the reactivity (No. of oscillations) with respect to $\mathrm{Mn}^{2+}$ ion follows the order:

$p$-HBA $>3,4-$ DHBA $>3,4,5$-THBA 
However, tannic acid, a resinous polymeric trihydroxybenzoic acid shows excellent oscillation of high frequency due to the presence of large number of free hydroxyl groups which activate the position for bromination to occur. The overall reactivity of these isomers with respect to different metal ion catalysts can not be predicted. This is owing to the varying extent of formation of bromoderivative and its expected oxidation to release bromide ionis which would act as inhibitor. Morever, the mechanism of reaction of $\mathrm{Fe}^{3+}$ and $\mathrm{Mn}^{3+}$ with $\mathrm{HBrO}_{2}$ would be different for which detailed kinetic studies are needed.

From the mechanistic point of view, our uncatalysed systems easily follow the OKN mechanism in which the process $\mathrm{B}$ of the FKN mechanism is modified by the replacement of the metal ion oxidation of $\mathrm{BrO}_{2}$, i.e.,

$\mathrm{BrO}_{2}^{\cdot}+\mathrm{Ce}^{3+}+\mathrm{H}^{+} \rightleftharpoons \mathrm{Ce}^{4+}+\mathrm{HBrO}_{2}$

by the reaction,

$\mathrm{BrO}_{2} \cdot+\mathrm{C}_{6} \mathrm{H}_{5}-\mathrm{OH}=\mathrm{HBrO}_{2}+\mathrm{C}_{6} \mathrm{H}_{5}-\mathrm{O}^{\cdot}$

Besides, it is important to note that autocatalytic reaction in catalysed $(\mathrm{FKN})$ and uncatalysed $(\mathrm{OKN})$ reactions involve different species such as,

Uncatalysed:

$\mathrm{BrO}_{2} \cdot+\mathrm{HAr}(\mathrm{OH})_{2} \rightarrow \mathrm{HBrO}_{2}+\mathrm{HAr}(\mathrm{OH}) \mathrm{O} \cdot$

$2 \mathrm{HBrO}_{2} \rightarrow \mathrm{BrO}_{3}^{-}+\mathrm{HOBr}+\mathrm{H}^{+}$

Catalysed:

$\mathrm{BrO}_{3}^{-}+\mathrm{HBrO}_{2}+\mathrm{H}^{+} \rightarrow 2 \mathrm{BrO}_{2}^{-}+\mathrm{H}_{2} \mathrm{O}$

$\mathrm{Mn}^{2+}+\mathrm{BrO}_{2}^{\cdot}+\mathrm{H}^{+} \rightarrow \mathrm{Mn}^{3+}+\mathrm{HBrO}_{2}$

However, the inhibitory reactions are same in both catalysed and uncatalysed systems, i.e.,

$\mathrm{HBrO}_{2}+\mathrm{Br}^{-}+\mathrm{H}^{+} \rightarrow 2 \mathrm{HOBr}$

\section{Conclusions}

From the discussion, it becomes apparent that in general catalysed systems show pronounced oscillatory characteristics as compared to uncatalysed ones. However, the oscillatory behaviour of the catalysed systems varies with different metal ions as catalysts. This is because of the varying redox potential of the metal ions vis-à-vis the system. Morever, the autocalytic reactions are also different with different metal ions.

\section{References}

1. Field, R. J.; Burger, M.; Oscillations and Travelling Waves in Chemical Systems, Willey Interscience: New York, 1985.

2. Koros, E.; Orban, M.; Nature (London, U. K.) 1978, 273, 371.

3. Noyes, R. M.; J. Am. Chem. Soc. 1980, 102, 4644.

4. Orban, M.; Koros, E. J.; Phys. Chem. 1978, 82, 1672.

5. Srivastava, P. K.; J. Ind. Chem. Soc. 1989, 66, 304.

6. Field, R. J.; Koros, E.; Noyes, R. M.; J. Am. Chem. Soc. 1972, 94, 8649.

7. Herbine, P.; Field, R. J.; J. Phys. Chem. 1980, 84, 1330.

8. Liu, J.; Scott, S. K.; J. Chem. Soc. Faraday Trans. 1991, 87, 2135.

9. Liu, J.; Scott, S. K.; J. Chem. Soc. Faraday Trans. 1992, 88, 909.

10. Gyorgyi, L.;Varga, M.; Koros, E.; Field, R. J.; Ruoff, P.; J. Phys. Chem. 1989, 93, 2836.

11. Orban, M.; Koros, E.; Noyes, R. M.; J. Phys. Chem. 1979, 83, 3056.

12. Koros, E.; Orban, M.; Habon, I.; J. Phys. Chem. 1980, 84, 559.

Received: March 22, 2008

Web Release Date: October 15, 2008 